\title{
Influence of climate variability on wine regions in the western USA and on wine quality in the Napa Valley
}

\author{
Gregory V. Jones ${ }^{1, *}$, Gregory B. Goodrich ${ }^{2}$ \\ ${ }^{1}$ Department of Geography, Southern Oregon University, Ashland, Oregon 97520, USA \\ ${ }^{2}$ Department of Geography \& Geology, Western Kentucky University, Bowling Green, Kentucky 42101, USA
}

\begin{abstract}
Trends in climate variables important to winegrape production in the western United States include fewer frost days, longer growing seasons, and higher spring and growing season temperatures. These trends have been related to a steady increase in wine quality and a decrease in year-to-year variability. While the trends in climate have been linked to increasing sea surface temperatures in the eastern Pacific, it is unknown whether this is caused by climate change or may be part of natural oscillations in the Pacific. In this study, 15 climate variables important to winegrape production were analyzed for 10 wine regions over the western USA. The variables were stratified by phases of the El Niño-Southern Oscillation (ENSO) and the Pacific Decadal Oscillation (PDO), both separately and then in combination (modulation effect) to determine if there are any significant differences between teleconnections. 'Wine Spectator' vintage ratings for Cabernet Sauvignon wines from the Napa Valley were also stratified by the same method, and multivariate statistics were used to determine which variables are most important to wine quality. ENSO phase by itself was not found to be important to either climate variability in wine regions in the western USA or wine quality in Napa Valley, but the cold phase of the PDO was found to be associated with increased spring frosts and a shorter growing season that results in lower ratings relative to warm PDO. The combination of neutral ENSO conditions during the cold phase of the PDO was nearly always associated with low quality wine in the Napa Valley, which is a function of cold springs with increased frost risk, cool growing seasons, and ripening period rainfall (cold PDO), and above-average bloom and summer rainfall (neutral ENSO). Although climate trends toward generally warmer growing seasons with less frost risk have occurred, this research highlights the impact of climate variability on wine quality where, should the PDO return to a multi-decadal cold phase, wine growers in the Napa Valley and across the western USA will likely experience greater variability in wine quality.
\end{abstract}

KEY WORDS: Climate variability - El Niño-Southern Oscillation - Pacific Decadal Oscillation · Winegrapes $\cdot$ Wine $\cdot$ Vintage ratings

Resale or republication not permitted without written consent of the publisher

\section{INTRODUCTION}

The El Niño-Southern Oscillation (ENSO) phenomenon has historically been an important part of life on the west coast of North America, but has clearly been more prominent since the 1982/1983 El Niño event that brought the term into the popular lexicon. Meteorologically, El Niño is associated with above-average winter precipitation in California and below-average winter precipitation in the Pacific Northwest (Glantz 2001). However, El Niño events have often been portrayed in a destructively negative manner by the media, which has led wine growers in the western United States to negatively associate winegrape production and subsequent wine quality with El Niño. This view of El Niño persists despite the fact that there is no research to suggest a negative relationship between any phase of ENSO and winegrape production 
and wine quality in the western United States. While the ENSO signal has been detected in time series of wine quality and winegrape production in Spain (Rodo \& Comin 2000) and Portugal (Esteves \& Orgaz 2001), no such studies have examined this relationship for the western United States. Ironically, another mode of climate variability in the Pacific Ocean, the Pacific Decadal Oscillation (PDO), has been shown to significantly impact California wine, although research in this area has not focused on regions outside of the Napa and Sonoma Valleys. Nemani et al. (2001) found that the most recent warm phase of the PDO (1977 to 1998) was associated with higher winter and spring temperatures, fewer frost days, and a longer growing season among other things, than the preceding cold phase of the PDO. All of the changes to Napa and Sonoma Valley climate were beneficial to winegrape production and wine quality. They concluded that, while the climatic changes were highly correlated to increases in eastern Pacific Ocean SSTs, there is no way to conclusively determine whether they were related to natural climate variability (PDO) or climate change.

The purpose of this research is to examine the influence of Pacific Ocean variability on the spatial structure and variability of climatic variables important to winegrape production in the western United States wine regions (Fig. 1). Climate teleconnections representing 2 temporal modes of Pacific sector climate variability, the PDO (multi-decadal) and ENSO (interannual) were split into their various phases to determine the individual impacts of the teleconnections on the climate variables. Since the strength of the ENSO climate signal has been shown to vary with the underlying phase of the PDO (Gershunov \& Barnett 1998), the set of years of individual ENSO phases were also split by PDO phase to account for the modulation of the ENSO signal. Difference of means testing was used to determine significant relationships between climate structure across the western United States and the various phases of PDO and ENSO. In addition, this analysis also specifically examined the relationship between the 2 climate teleconnections and wine quality in the important wine region of Napa Valley. A principal components analysis (PCA) was used to reduce the climate variables important to winegrape production in Napa Valley into the primary modes of variability. The principal components were then regressed with 'Wine Spectator' vintage ratings to determine the key climate variables that influence Napa Valley vintages. Finally, the research discusses how the synoptic conditions present during certain combinations of ENSO and PDO produce higher/lower quality wine due to the influence of the teleconnections on certain climate variables.

\section{DATA AND METHODS}

\subsection{Regional climate data}

Jones (2005b) studied the structure and trends in temperature-related parameters for California, Oregon, and Washington grape growing regions for the years 1948 to 2002 using the United States Historical Climatology Network (USHCN) climate database. The present paper updates the Jones (2005b) research by adding more stations and including precipitation variables important to growing quality winegrapes. The

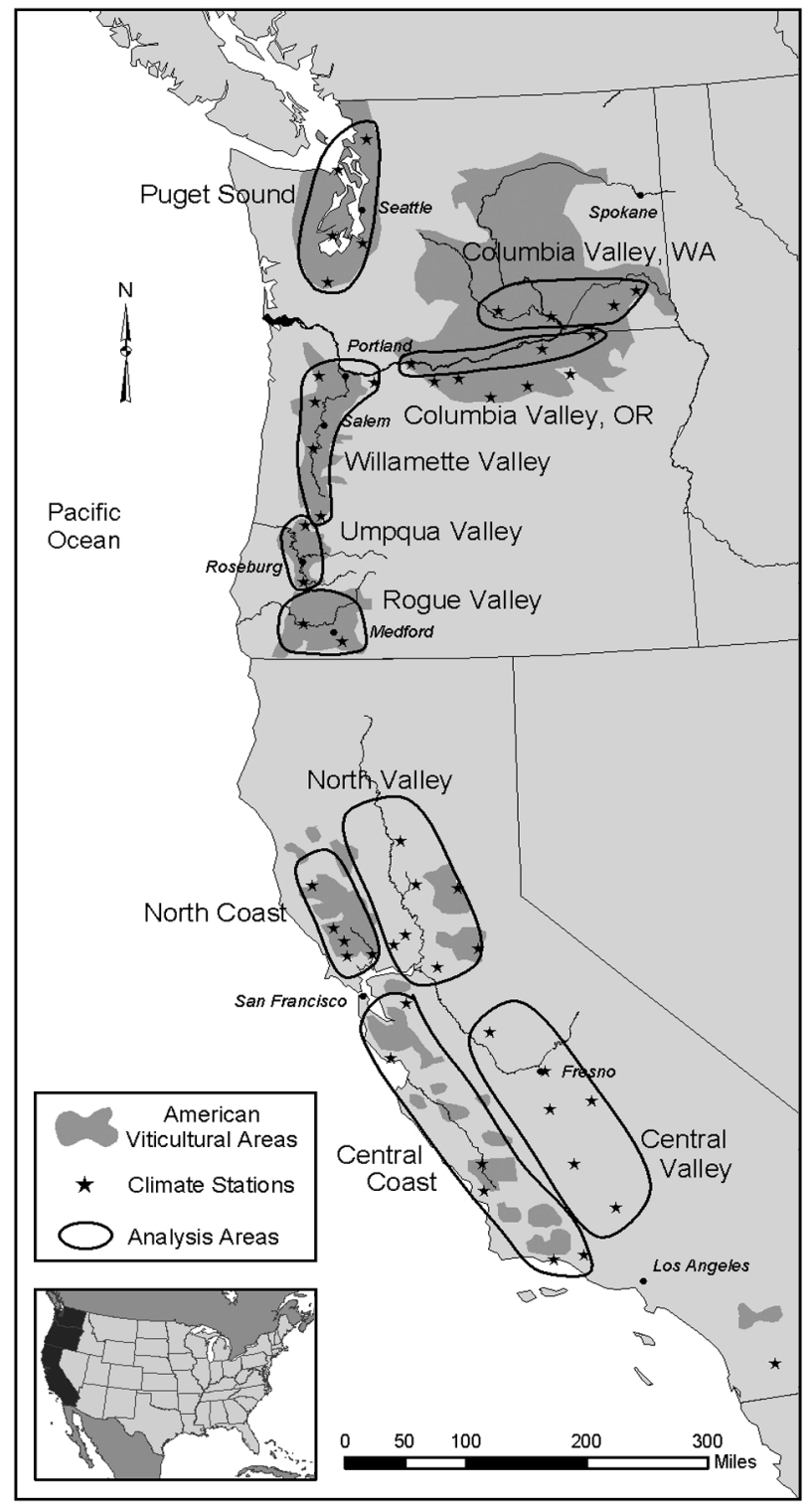

Fig. 1. Spatial depiction of the western United States American Viticultural Areas (AVAs), the general winegrape growing regions studied, and the United States Historical Climatology Network cooperative stations used in the analysis (see Jones $2005 \mathrm{~b}$ for more details on the stations used) 
USHCN database represents a single, consistent, longterm set of $>1000$ cooperative observing stations in the United States (Easterling et al. 1999). The data have undergone rigorous testing to ensure that bias from urbanization, station moves, and instrument changes have been minimized or corrected. Data for California, Oregon, and Washington winegrape growing regions were extracted, resulting in 44 stations being selected (22 stations in California, 13 stations in Oregon, and 9 stations in Washington; Fig. 1). The stations selected were meant to represent either specific American Viticultural Areas (AVAs; governmentally defined production regions), such as in Oregon and Washington, or broad grape growing areas, such as in California (Fig. 1). The data aggregation and processing results in 10 regions depicting the climate structure, variability, and trends associated with the average climate of each region. In addition, to capture a longer time period for the teleconnection analysis with wine quality, the above methods were also applied to 2 stations in the Napa Valley. The climate stations at Napa State Hospital and St. Helena represent the cooler southern and warmer northern sections of the valley, respectively, and climate data for 1930 to 2002 were averaged to produce a mean valley dataset.

While some missing data were evident in the USHCN, restricting the time period to 1948 to 2002 for the western United States and the 2 locations in the Napa Valley for 1930 to 2002 resulted in the chosen stations having $<5 \%$ of their individual records missing. If missing data were encountered, only those months with $<5 \%$ missing observations were used in the analysis. If $<5 \%$ missing observations were encountered, the missing data points were replaced by an average of the $2 \mathrm{~d}$, both before and after the missing observations or by the region-wide average for that region when multiple days in a row were missing.

To analyze the climate structure in these regions, daily maximum and minimum temperatures and precipitation from the USHCN were used to derive 15 climatically important parameters for winegrape growing (Jones 2005b). Five of the parameters represent temperature or heat accumulation characteristics, including:

(1) Growing season (April to October) average temperature (Tavg)

(2) Growing season average maximum temperature (Tmax)

(3) Growing season average minimum temperature (Tmin)

(4) Ripening period (15 August to 15 October) average temperature (RTavg)

(5) Growing degree-days using a base of $10^{\circ} \mathrm{C}$ with no upper cut-off (GDD), calculated as:

$$
\sum_{\text {Apr } 1}^{\text {Oct } 31}\left[\left(\overline{T^{\circ} \mathrm{C}}\right)\left(-10^{\circ} \mathrm{C}\right)\right]=\mathrm{GDD}
$$

Six additional parameters represent frost-related characteristics and, while the definition of what constitutes the critical minimum temperature that results in frost damage for individual crops varies, this research examines only those occurrences below $0^{\circ} \mathrm{C}$ and includes:

(6) The number of frost days on an annual basis (July through June)

(7) The number of frost days during the spring (March, April, and May)

(8) The number of frost days during the fall (September, October, and November)

(9) The last date of spring frost

(10) The first date of fall frost

(11) The length of the frost-free period (defined as the difference between a given year's last frost in the spring and first frost in the fall)

The final 4 parameters represent precipitation characteristics, including:

(12) Winter precipitation (November to March) (Wprecip)

(13) Growing season precipitation (April to October) (GSprecip)

(14) Bloom period precipitation (15 May to 15 June) (Bprecip)

(15) Ripening period precipitation (15 August to 15 October) (Rprecip)

The 15 parameters were analyzed for each of the 44 stations individually, averaged by region, and were subtracted from the long-term, region-wide average to create a time series of anomalies. In addition, the same procedure was done for the longer time period for the Napa Valley's 2 stations. Overall descriptive statistics were calculated for each parameter, in each individual region and the Napa Valley. In addition, region-wide and Napa Valley time series were checked for firstorder autocorrelation using the Durbin-Watson statistic. Finding no autocorrelation problems, the time series was then analyzed for trends using linear regression and 5 yr moving averages.

\subsection{ENSO-PDO time series}

This research uses the method outlined in Trenberth (1997) to determine years of El Niño, La Niña, and neutral ENSO. When the 5 mo moving average of Niño-3.4 $\left(5^{\circ} \mathrm{N}\right.$ to $5^{\circ} \mathrm{S}, 120$ to $\left.170^{\circ} \mathrm{W}\right)$ anomalies exceeds $+0.4(-0.4)$ for 6 consecutive months, an El Niño (La Niña) event was said to occur. All other periods were considered neutral ENSO. If the El Niño or La Niña event occurred during the July to November 
period preceding a particular winter, then that winter was classified accordingly. Since most ENSO events last between 9 and $12 \mathrm{mo}$, that winter's ENSO conditions generally persist throughout the following growing season. Using this method, there are 19 El Niño years, 17 La Niña years, and 30 yr of neutral ENSO during the period of record from 1933 to 1998 (truncated to match the PDO, see below). The dataset used in this study was the Kaplan extended Niño-3.4 data set (Kaplan et al. 1998) and was obtained from the International Research Institute for Climate Prediction (IRI) data library (available online at http://ingrid.ldeo. columbia.edu/SOURCES/.KAPLAN/.EXTENDED/).

The PDO is related to low-frequency variability in sea surface temperatures (SSTs) in the extratropical Pacific Ocean (Frauenfeld et al. 2005), with a period of around $50 \mathrm{yr}$. The PDO index is the leading principal component or eigenvector of the mean monthly SSTs in the Pacific Ocean north of $20^{\circ} \mathrm{N}$ latitude (Mantua et al. 1997) and is most prominent in November to March. Positive (warm phase) values of the PDO refer to above normal SSTs along the west coast of North America and along the equator and below normal SSTs in the central and western North Pacific centered around $45^{\circ} \mathrm{N}$ latitude. Negative values of the PDO refer to the opposite distribution of SSTs in these same areas. Rather than using annual or seasonal index values, multi-decadal warm and cold phases were used to delineate changes in the PDO (Gershunov \& Barnett 1998, Gutzler et al. 2002). Mantua \& Hare (2002) suggest there have only been 2 complete cycles of the PDO since 1890 (warm; 1925 to 1946 and 1977 to 1998 ; cold: 1890 to 1924 and 1947 to 1976 ). While the PDO may have shifted to a cold phase beginning in 1999 (Hare \& Mantua 2000, Schwing \& Moore 2000), most scientists agree that this may not be known for several years (Mantua \& Hare 2002, Chavez et al. 2003, N. J. Mantua pers. comm.). For this reason, the analysis was truncated to 1998 ; however, the possibility of, and implications for a shift to cold PDO in 1999 is expounded upon in Section 4 of this paper. The PDO dataset used in this study was obtained online from the Joint Institute for the Study of Atmosphere and Oceans (JISAO) at the University of Washington (http://jisao.washington.edu/pdo/ PDO.latest).

Unlike ENSO, where much is known about the physics that give rise to its occurrence, there is greater uncertainty regarding the physical mechanisms of the PDO as well as the complexity of its relationship to ENSO. Some have suggested that the PDO represents the ENSO signal plus red noise (Gedalof et al. 2002, Newman et al. 2003), while others more recently suggest that the PDO is a function of the superposition of SST fluctuations emanating from dynamical modes such as ENSO and the KuroshioOyashio Extension, among others (Schneider \& Cornuelle 2005). Other research has shown that decadal variability in the North Pacific may result from shifts in the main teleconnection centers between El Niño and La Niña years and the nonlinearity of the tropical and extra-tropical Pacific (An et al. 2007). Regardless of the relationship between the PDO and ENSO, it is well known that the usefulness of ENSO as a seasonal predictive tool does vary with the phase of the PDO (Gershunov \& Barnett 1998, McCabe \& Dettinger 1999).

Nemani et al. (2001) and Jones (2005b) found that most of the important climate variables that influence winegrape production in Napa and Sonoma Valleys (North Coast) displayed a steady upward trend since 1948 (e.g. growing degree-days, Fig. 2). Since many of the climate variables in these studies are highly correlated to eastern Pacific SSTs and many display a steadily increasing trend, it points to a climate change influence. However, certain variables from those studies (Fig. 3), display a step-change that corresponds to the 1976 to 1977 climate shift in the Pacific Ocean that is believed to represent a phase change in the PDO from cold to warm (Mantua et al. 1997). It was this step-change in some of the variables that led to the consideration that natural variability in the Pacific Ocean may be responsible for at least some of the changes noted in regional climate structure and wine-

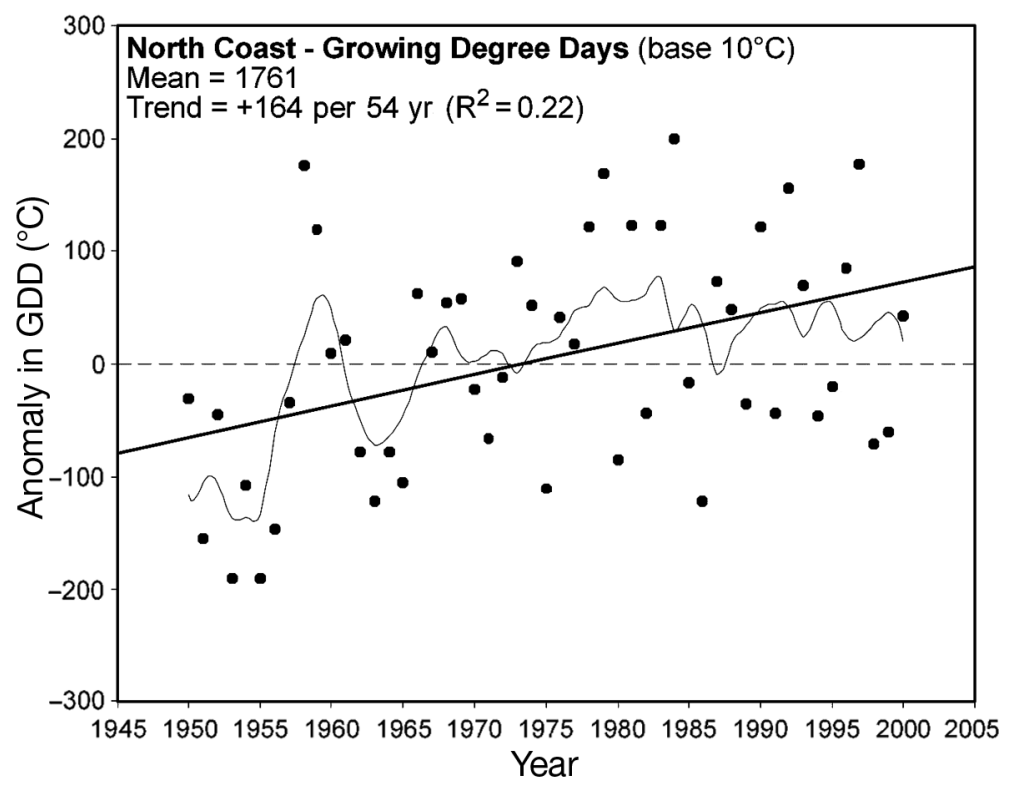

Fig. 2. Trend and 5 yr moving averages for the Napa and Sonoma Valleys (North Coast) growing degree-days (GDD, base $10^{\circ} \mathrm{C}$ ) from 1948 to 2002 . Values depicted are anomalies in GDD with means and trends over the entire time period shown (statistics in Table 1) 


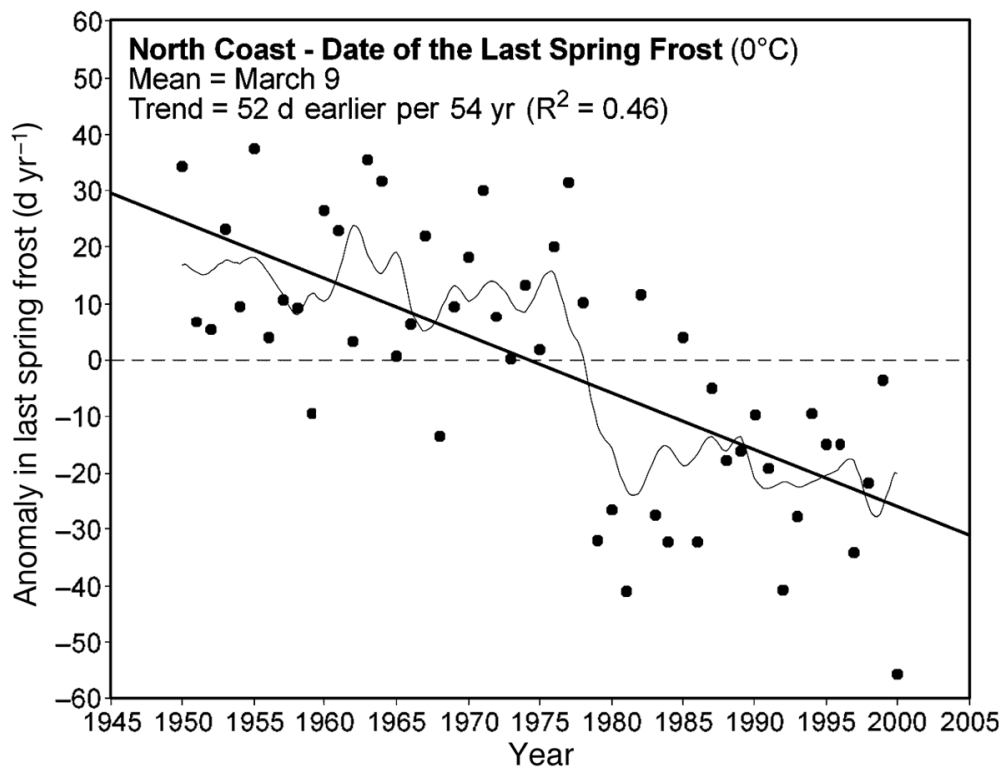

Fig. 3. Trend and 5 yr moving averages for the North Coast dates of the last spring frost (below $0^{\circ} \mathrm{C}$ ) from 1948 to 2002. Values depicted are anomalies in the number of days with means and trends over the entire time period shown (statistics in Table 2)

grape production and wine quality in the western United States since 1950. To test this, the 11 temperature and 4 precipitation variables averaged over each of the 10 west coast wine regions and the Napa Valley were stratified by years of El Niño, La Niña, and neutral ENSO and then separately by years of warm and cold PDO to determine if there were significant differences between the various phases of each teleconnection. Finally, in order to determine the significance of the ENSO-PDO modulation of the regional climates of the wine regions and wine quality in the Napa Valley, difference-of-means tests were performed on the characteristic structure for each of the 6 possible ENSO-PDO categories. This method follows that of Goodrich (2007), which has proven to be useful in understanding the effect of the PDO on winter precipitation and drought during years of neutral ENSO.

\section{3. 'Wine Spectator' vintage ratings}

The most common metrics used by the public, the wine industry, and in academic research for yearto-year comparisons of wine quality are either prices or vintage ratings (Ashenfelter et al. 1995, Jones \& Storchmann 2001). The relationships between climate, quality, and price are simple; beneficial growing seasons produce higher quality fruit, that when processed into wine, obtains higher ratings and therefore higher prices on the market. However, long-term consistent price data for multiple regions and wine styles over many years are not readily available and, even if available, have the additional influence of availability (scarcity). Vintage ratings, on the other hand, are available from numerous sources (Jones et al. 2005), for many wine regions and wine styles, and cover fairly long time periods (i.e. 20 to 50 yr or more). Vintage rating systems are typically based upon categorical estimates from bad to exceptional quality or numerical scores that range from 0 to 20 or 0 to 100 , with higher values representing higher quality. Vintage ratings are compiled either for single wines from a given producer, or are aggregated to represent a region-wide rating value. While rating systems vary in terms of their structural categories or scales, their overall goal is to provide a system of classification by either single judges or panels, which assesses each vintage's wine based upon flavor, aroma, body, color, and the balance of alcohol and acidity typical of a given wine style.

Research using vintage ratings has found that they accurately reflect the weather factors long known to determine wine quality (Ashenfelter \& Jones 2000). Jones \& Davis (2000) also found strong connections between climate, grapevine phenology, fruit composition, and vintage ratings for Bordeaux, France. Nemani et al. (2001) also showed how ratings impact price with an average rating increase of 10 points (on a 0 to 100 scale), resulting in a $220 \%$ increase in price per bottle for the 1995 vintage in the Napa Valley of California. Furthermore, Jones et al. (2005) found that vintage ratings for 27 of the world's best wine regions have shown trends of increasing overall quality with less vintage-to-vintage variation and that growing season temperatures are important factors in vintage ratings. While varying by the region and wine type, the average marginal effect of the growing season temperatures show that a $1.0^{\circ} \mathrm{C}$ warmer vintage results in an average 13 rating point increase.

While numerous rating systems, compiled over various time periods and by various sources (e.g. 'Sotheby's', 'Wine Enthusiast', 'Wine Spectator', 'Wine Advocate', and others), exist, correlations between the various sources are generally strong ( $\mathrm{r}>0.9)$, indicating that this subjective measure of quality is a good quantitative representation of a vintage (Jones 1997). Reisman et al. (2003), comparing the 'Wine Enthusiast', 'Wine Spectator', 'Wine Advocate' rating systems for the north coast region of California and Cabernet Sauvignon wines, also showed that vintages clearly vary in terms of quality, but that the different rating 
systems do not differ significantly on a year-to-year basis. Furthermore, Jones (2005a) compared wine composition data (sugar levels and potential alcohol) with vintage ratings for the same 3 rating systems as in Reisman et al. (2003) and found that from an economic perspective the 'Wine Spectator' is the more important rating system for Napa Valley Cabernet Sauvignon wines.

Therefore, this research uses the 'Wine Spectator' vintage ratings (WSR) for Cabernet Sauvignon wines from the Napa Valley for the 1933 to 2002 vintages (Laube 1989, Wine Spectator 2004) to determine the impact of ENSO and PDO on wine quality (truncated to 1998 to match the PDO). While the results of this section of the analysis are specific only to the Napa Valley, this methodology could be repeated for any number of vintages for each wine region in the western United States, as long as an appropriate rating scale is available. Since Napa Valley is the premier wine region in the United States, we feel that the Cabernet Sauvignon ratings will showcase the impact of teleconnections on an important component of the United States wine industry. WSR from 1933 to 2002 (Fig. 4) have an average score of 86 , with a standard deviation of 8.1 , and achieved the highest score (98) in 1997 and the lowest score (67) in 1953. The time series shows that wine quality has steadily increased since the 1950s as climatic conditions have become more favorable to wine production (Nemani et al. 2001, Jones 2005a). There has also been substantially less variability in the form of fewer poor vintages since the late 1970s. While some of this trend and reduced variability is likely due to better plant material and increased technology in the vineyard and winery, our concern here was whether the increase in quality was driven by natural oscillations in climate or by climate change. The goal of this

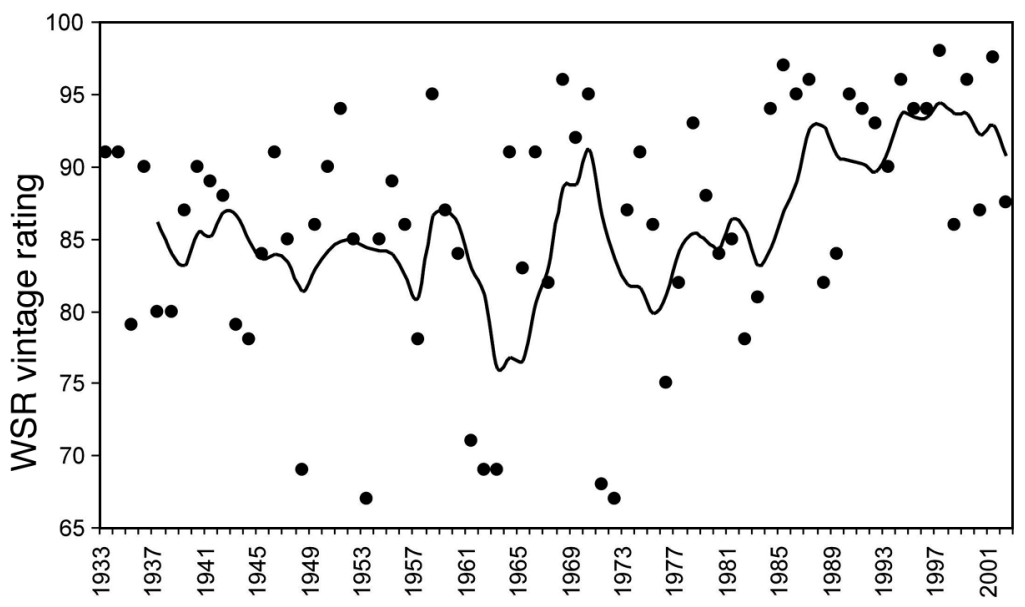

Fig. 4. 'Wine Spectator' vintage ratings (WSR) for Napa Valley Cabernet Sauvignon vintages from 1933 to 2002 (Laube 1989, Wine Spectator 2004). Line: 5 yr moving average section of the analysis was to determine if there was a specific teleconnection phase that was consistently associated with high or low quality wine and, more specifically, which of the 15 climate variables known to impact winegrape production are most important to achieving high (or low) vintage ratings.

\section{RESULTS}

\subsection{Regional climate analysis}

\subsubsection{Temperature}

Growing degree-days over the 10 western United States wine regions (Fig. 1) range from a low of 972 in the Puget Sound region to a high of 2618 in the Central Valley (Table 1). Variability in degree-days averages roughly 120 from year to year, with the lowest variations in the Puget Sound and North Coast regions and the greatest year-to-year variation in the North Valley region. Over the time period each of the regions has experienced statistically significant changes, with an average increase of 171. For example, the North Coast region has trended upward 160 degree-days over the 55 yr from 1948 to 2002 (Fig. 2). Jones (2005b) has shown that growing season average, maximum, and minimum temperatures also follow a general northsouth gradient from the lowest in the Puget Sound to the highest in the Central Valley, with some minor differences in minimum temperatures that are driven by elevation. Overall, positive trends in these 3 temperature parameters were seen across each region with significant trends in 9 of 10 regions for average temperatures, 5 of 10 regions for maximum temperatures, and all regions for minimum temperatures (Jones 2005b). Average growing season temperatures increased from 0.6 to $1.4^{\circ} \mathrm{C}$ across the regions with an overall average increase of $0.9^{\circ} \mathrm{C}$. Maximum temperature changes were much less significant, with an overall warming averaged across all regions of $1.0^{\circ} \mathrm{C}$. Minimum temperatures changed more significantly than maximums, with trends that range from 0.8 to $1.9^{\circ} \mathrm{C}$ and averaged $1.3^{\circ} \mathrm{C}$. Ripening period average temperatures have similar north-south spatial variations and generally warmed over the time period, with 7 of the regions experiencing significant trends ranging from 0.8 to $1.4^{\circ} \mathrm{C}$ (Jones 2005b).

In terms of annual, spring, and fall frost frequencies, Jones (2005b) found that most regions have seen a decline in the overall number of days $<0^{\circ} \mathrm{C}$. The annual fre- 
Table 1. Descriptive statistics (mean, $\mathrm{SD}$, max., min.) and trends $\left(\mathrm{R}^{2}, \mathrm{p}\right.$, decadal/ overall) for growing degree-days (GDD) above a base of $10^{\circ} \mathrm{C}$ (with no upper cutfrom 1948 to 2002 (Jones 2005b)

\begin{tabular}{|lccccccccc|}
\hline Region & Mean & SD & Max. Min. & $\mathrm{R}^{2}$ & $\mathrm{p}$ & $\begin{array}{c}\text { Trend } \\
\text { Decadal }\end{array}$ \\
& & & & & & & & & \\
\hline Puget Sound & 972 & 102 & 1267 & 730 & 0.13 & $<0.01$ & 23 & 127 \\
Willamette Valley & 1142 & 122 & 1503 & 858 & 0.27 & $<0.01$ & 39 & 215 \\
Umpqua Valley & 1319 & 120 & 1660 & 1036 & 0.14 & $<0.01$ & 25 & 138 \\
Rogue Valley & 1460 & 116 & 1723 & 1208 & 0.09 & $<0.05$ & 21 & 116 \\
Columbia Valley, OR & 1489 & 125 & 1830 & 1215 & 0.11 & $<0.05$ & 50 & 275 \\
Columbia Valley, WA & 1504 & 124 & 1762 & 1216 & 0.13 & $<0.01$ & 27 & 149 \\
Central Coast & 1724 & 117 & 2001 & 1495 & 0.15 & $<0.01$ & 29 & 160 \\
North Coast & 1761 & 105 & 1962 & 1513 & 0.22 & $<0.01$ & 31 & 171 \\
North Valley & 2267 & 137 & 2569 & 1910 & 0.22 & $<0.01$ & 40 & 220 \\
Central Valley & 2618 & 127 & 2922 & 2299 & 0.21 & $<0.01$ & 36 & 198 \\
\hline
\end{tabular}
off) from April through October for the 10 western United States wine regions

Columbia Valley regions and the Rogue Valley. The average latest first fall frosts occur from the third to fourth weeks in November in the California regions. The variability in the first fall date was similar to that observed for spring, and, interestingly, the regions that experience early last spring frosts and late first fall frosts typically have greater variability in the timing of the events (Jones 2005b). The average earliest fall frosts during the time period came in the second week of September for the Columbia, Rogue, and Umpqua Valleys. Trends in fall frost timing were less significant and of quency of frost occurrence was greatest in the Columbia Valley regions of Oregon and Washington, with $>100 \mathrm{~d} \mathrm{yr}^{-1}$ on average, while the lowest occurrence was in the coast and valley regions of California, where typically only 24 to $27 \mathrm{~d} \mathrm{yr}^{-1}$ drop below $0^{\circ} \mathrm{C}$. Significant trends in annual frost occurrence show declines across all regions averaging 18 fewer $\mathrm{d} \mathrm{yr}^{-1}$. Spring frost frequency shows similar north-south ranking and has shown an average reduction across the 10 regions, with significant trends of $7 \mathrm{~d} \mathrm{spring}^{-1}$. Note that some regions have had trends such that spring frosts are rare occurrences today. Fall frost frequency also follows the same spatial pattern, with some regions experiencing very few frosts; however, the trends in fall frost frequencies were much less significant across all regions and average only $3 \mathrm{~d}$.

The timing of frost events in the spring and fall are typically very important factors in damaging either the young shoots or ripening fruit. On average, last spring frosts occurred from as early as the last week in February in the Central Valley to as late as 11 May in Columbia Valley, Oregon (Table 2). Standard deviations in spring frost dates indicate that most regions experience a window of frost potential of 10 to $22 \mathrm{~d}$ from their respective mean dates. The average latest dates for spring frosts during the time period occurred in the last $2 \mathrm{wk}$ of May and the earliest in the middle of January. All regions showed statistically significant trends toward earlier last spring frosts, with an average change of $25 \mathrm{~d}$ and a maximum change of $53 \mathrm{~d}$ experienced in the North Coast area (Table 2). The first frosts each fall come as early as the first and second week in October in the lower magnitude than in spring, with changes that average $10 \mathrm{~d}$ later across the regions.

For the time period, the frost-free season ranged from 147 to $273 \mathrm{~d}$ for the Columbia Valley, Oregon, and the Central Valley, respectively (not shown). The overall length of the frost-free periods typically vary from 14 to $30 \mathrm{~d}$ across the regions and have been as short as $123 \mathrm{~d}$ (Columbia and Umpqua Valleys, Oregon) to as long as $319 \mathrm{~d}$ (North Coast). All regions exhibited trends towards longer frost-free periods, with 9 of the 10 regions having significant trends ranging from 17 to $68 \mathrm{~d}$ and averaging $38 \mathrm{~d}$.

\subsubsection{Precipitation}

Precipitation amounts across the wine regions of the western United States show the expected northsouth and coastal-inland patterns. Winter precipitation amounts were greatest in the Willamette Valley (912 mm) and lowest in the Columbia Valleys of Wash-
Table 2. Descriptive statistics (mean, SD, max., min.; data are dates [month/day]) and trends $\left(\mathrm{R}^{2}, \mathrm{p}\right.$, decadal/overall trend; data in days) for last date of spring frost $\left(0^{\circ} \mathrm{C}\right)$ for the 10 western United States wine regions from 1948 to 2002 (Jones 2005b)

\begin{tabular}{|lccccccccc|}
\hline Region & Mean & SD & Max. & Min. & $\mathrm{R}^{2}$ & $\mathrm{p}$ & $\begin{array}{c}\text { Trend } \\
\text { Decadal }\end{array}$ \\
& & & & & & & & \\
& & & & & & & & & \\
Central Valley & $2 / 25$ & 16.7 & $3 / 30$ & $1 / 14$ & 0.13 & $<0.01$ & -3.8 & -21 \\
North Valley & $3 / 5$ & 16.9 & $4 / 8$ & $1 / 17$ & 0.09 & $<0.05$ & -3.3 & -18 \\
Central Coast & $3 / 8$ & 18.7 & $4 / 15$ & $1 / 18$ & 0.26 & $<0.01$ & -6.3 & -35 \\
North Coast & $3 / 9$ & 22.4 & $4 / 22$ & $1 / 13$ & 0.46 & $<0.01$ & -9.6 & -53 \\
Puget Sound & $4 / 9$ & 15.2 & $5 / 7$ & $3 / 4$ & 0.31 & $<0.01$ & -5.0 & -28 \\
Umpqua Valley & $4 / 20$ & 17.7 & $5 / 17$ & $2 / 28$ & 0.23 & $<0.01$ & -5.4 & -30 \\
Willamette Valley & $4 / 25$ & 13.6 & $5 / 21$ & $3 / 21$ & 0.17 & $<0.01$ & -3.5 & -19 \\
Columbia Valley, WA & $4 / 26$ & 11.4 & $5 / 16$ & $3 / 28$ & 0.20 & $<0.01$ & -3.1 & -17 \\
Rogue Valley & $5 / 5$ & 10.6 & $5 / 24$ & $4 / 9$ & 0.06 & $<0.1$ & -1.8 & -10 \\
Columbia Valley, OR & $5 / 11$ & 9.6 & $5 / 28$ & $4 / 14$ & 0.18 & $<0.01$ & -2.5 & -14 \\
\hline
\end{tabular}


ington $(191 \mathrm{~mm})$ and Oregon $(289 \mathrm{~mm})$ and the Central Valley of California $(212 \mathrm{~mm})$. Growing season precipitation ranges from 57 to $408 \mathrm{~mm}$, with the lowest values found in California and the highest values experienced in the coastal zones of Oregon and Washington (Table 3). Bloom (6 to $65 \mathrm{~mm}$ ) and ripening (10 to $110 \mathrm{~mm}$ ) period precipitation follows a similar spatial pattern to growing season rainfall, with greater amounts along the northern coastal regions (not shown). Trends in precipitation over the 1948 to 2002 time period were few, with no statistically significant trends in winter precipitation (not shown), although 5 regions had slight increases, while the Puget Sound region had a slight decrease. In addition, changes in growing season precipitation were not significant across the regions (Table 3). However, bloom period rainfall showed slight positive trends in 7 of the 10

Table 3. Descriptive statistics (mean, SD, max., min.) and trends $\left(\mathrm{R}^{2}, \mathrm{p}\right.$, decadal/ overall trend) for growing season (April to October) precipitation ( $\mathrm{mm}$ ) for the 10 western United States wine regions from 1948 to 2002 (Jones 2005b)

\begin{tabular}{|lcccccccrr|}
\hline Region & Mean & SD & Max. Min. & $\mathrm{R}^{2}$ & $\mathrm{p}$ & \multicolumn{2}{c|}{$\begin{array}{c}\text { Trend } \\
\text { Decadal }\end{array}$} \\
& & & & & & & & \\
& & & & & & & & & \\
Central Valley & 56.8 & 31.6 & 136.1 & 9.7 & 0.00 & 0.852 & 0.25 & 1.9 \\
Central Coast & 77.7 & 44.4 & 183.1 & 17.0 & 0.01 & 0.539 & -2.3 & -16.9 \\
North Valley & 101.1 & 51.9 & 240.5 & 16.0 & 0.02 & 0.399 & -3.8 & -28.2 \\
North Coast & 136.4 & 67.8 & 359.4 & 19.1 & 0.01 & 0.409 & -4.8 & -35.7 \\
Columbia Valley, WA & 137.9 & 37.1 & 267.0 & 64.8 & 0.00 & 0.679 & 1.3 & 9.4 \\
Columbia Valley, OR & 161.6 & 40.1 & 246.9 & 77.7 & 0.04 & 0.168 & 4.8 & 35.7 \\
Rogue Valley & 191.1 & 65.5 & 336.3 & 82.3 & 0.01 & 0.519 & -3.6 & -26.3 \\
Umpqua Valley & 273.7 & 85.4 & 494.8 & 82.6 & 0.01 & 0.507 & 5.3 & 39.5 \\
Puget Sound & 382.2 & 71.2 & 546.9 & 206.2 & 0.00 & 0.794 & -1.5 & -11.3 \\
Willamette Valley & 408.0 & 98.6 & 650.0 & 196.6 & 0.00 & 0.822 & 1.8 & 13.2 \\
\hline
\end{tabular}

regions, with the Puget Sound region having a significant increase of $25.9 \mathrm{~mm}$ over the time period. Ripening period rainfall trends revealed the opposite of the bloom period, with declines seen in 6 of the 10 regions. The Puget Sound, Willamette Valley, and Umpqua Valley each had significant declines in ripening period precipitation that averaged $45 \mathrm{~mm}$ for the time period (not shown).

\subsubsection{Napa Valley}

Over the longer time period (1930 to 2002) for the Napa Valley, trends generally follow those of the whole western United States wine regions described above (Table 4). Growing degree-days have averaged 1767, but ranged from a low of 1402 in 1930 to a high of 2113 in 1997. Decadal and time period trends of 46 decade and 336 per $73 \mathrm{yr}$, respectively, have been experienced in Napa. Growing season temperature characteristics reveal an average April to October temperature of $18.2^{\circ} \mathrm{C}$, with average maximum and minimum temperatures of 26.9 and $9.6^{\circ} \mathrm{C}$, respectively (Table 4). Trends in growing season temperatures show a dominant warming at night, with minimums increasing $2.9^{\circ} \mathrm{C}$ over the $73 \mathrm{yr}$ (Fig. 5), resulting in an average temperature increase of $1.5^{\circ} \mathrm{C}$ (Fig. 5). Ripening period (15 August to 15 October) temperatures have also

Table 4. Descriptive statistics and trends for the 15 climate parameters observed in the Napa Valley from 1930 to 2002 (United States Historical Climatology Network, data from 2004). Dates are month/day

\begin{tabular}{|c|c|c|c|c|c|c|c|c|}
\hline \multirow[t]{2}{*}{ Variable } & \multirow[t]{2}{*}{ Mean } & \multirow[t]{2}{*}{$\mathrm{SD}$} & \multirow[t]{2}{*}{ Max. } & \multirow[t]{2}{*}{ Min. } & \multirow[t]{2}{*}{$\mathrm{R}^{2}$} & \multirow[t]{2}{*}{$\mathrm{p}$} & \multicolumn{2}{|c|}{ Trend } \\
\hline & & & & & & & Decadal & Overall \\
\hline Growing degree-days (Apr-Oct, base $10^{\circ} \mathrm{C}$ ) & 1767 & 140 & 2113 & 1402 & 0.51 & $<0.01$ & 46 & 336 \\
\hline Growing season average temperatures (Apr-Oct) & 18.2 & 0.7 & 19.9 & 16.5 & 0.50 & $<0.01$ & $0.2^{\circ} \mathrm{C}$ & $1.5^{\circ} \mathrm{C}$ \\
\hline Growing season maximum temperatures (Apr-Oct) & 26.9 & 0.7 & 28.7 & 25.4 & 0.02 & 0.269 & $0.1^{\circ} \mathrm{C}$ & $0.6^{\circ} \mathrm{C}$ \\
\hline Growing season minimum temperatures (Apr-Oct) & 9.6 & 1.0 & 11.5 & 7.2 & 0.77 & $<0.01$ & $0.4^{\circ} \mathrm{C}$ & $2.9^{\circ} \mathrm{C}$ \\
\hline Ripening period average temperatures (15 Aug-15 Oct) & 19.5 & 0.8 & 21.1 & 17.5 & 0.38 & $<0.01$ & $0.2^{\circ} \mathrm{C}$ & $1.5^{\circ} \mathrm{C}$ \\
\hline Number of days below freezing, annually & 27 & 14 & 64 & 1 & 0.35 & $<0.01$ & $-3.9 \mathrm{~d}$ & $-29 \mathrm{~d}$ \\
\hline Number of days below freezing, spring (Mar-May) & 3 & 3 & 12 & 0 & 0.25 & $<0.01$ & $-0.8 \mathrm{~d}$ & $-6 \mathrm{~d}$ \\
\hline Number of days below freezing, fall (Sep-Nov) & 3 & 3 & 12 & 0 & 0.31 & $<0.01$ & $-0.8 \mathrm{~d}$ & $-6 \mathrm{~d}$ \\
\hline Date of last spring frost $\left(\leq 0^{\circ} \mathrm{C}\right)$ & $3 / 12$ & $1 / 30$ & $5 / 4$ & $1 / 8$ & 0.19 & $<0.01$ & $-6.0 \mathrm{~d}$ & $-44 \mathrm{~d}$ \\
\hline Date of first fall frost $\left(\leq 0^{\circ} \mathrm{C}\right)$ & $11 / 24$ & $1 / 20$ & $2 / 23$ & $10 / 18$ & 0.38 & $<0.01$ & $+5.6 \mathrm{~d}$ & $+41 \mathrm{~d}$ \\
\hline Frost-free period & 256 & 42 & 364 & 178 & 0.37 & $<0.01$ & $+11.6 \mathrm{~d}$ & $+85 \mathrm{~d}$ \\
\hline Winter precipitation (Nov-Mar) & 25.1 & 9.4 & 49.6 & 5.5 & 0.04 & 0.118 & $20.5 \mathrm{~mm}$ & $152 \mathrm{~mm}$ \\
\hline Growing season precipitation (Apr-Oct) & 4.9 & 2.5 & 12.2 & 0.5 & 0.01 & 0.955 & $-0.25 \mathrm{~mm}$ & $-1.8 \mathrm{~mm}$ \\
\hline Bloom period precipitation (15 May-15 Jun) & 0.6 & 0.8 & 3.9 & 0.0 & 0.01 & 0.828 & $0.26 \mathrm{~mm}$ & $1.9 \mathrm{~mm}$ \\
\hline Ripening period precipitation (15 Aug-15 Oct) & 0.9 & 1.5 & 11.3 & 0.0 & 0.01 & 0.804 & $-0.51 \mathrm{~mm}$ & $-3.8 \mathrm{~mm}$ \\
\hline
\end{tabular}




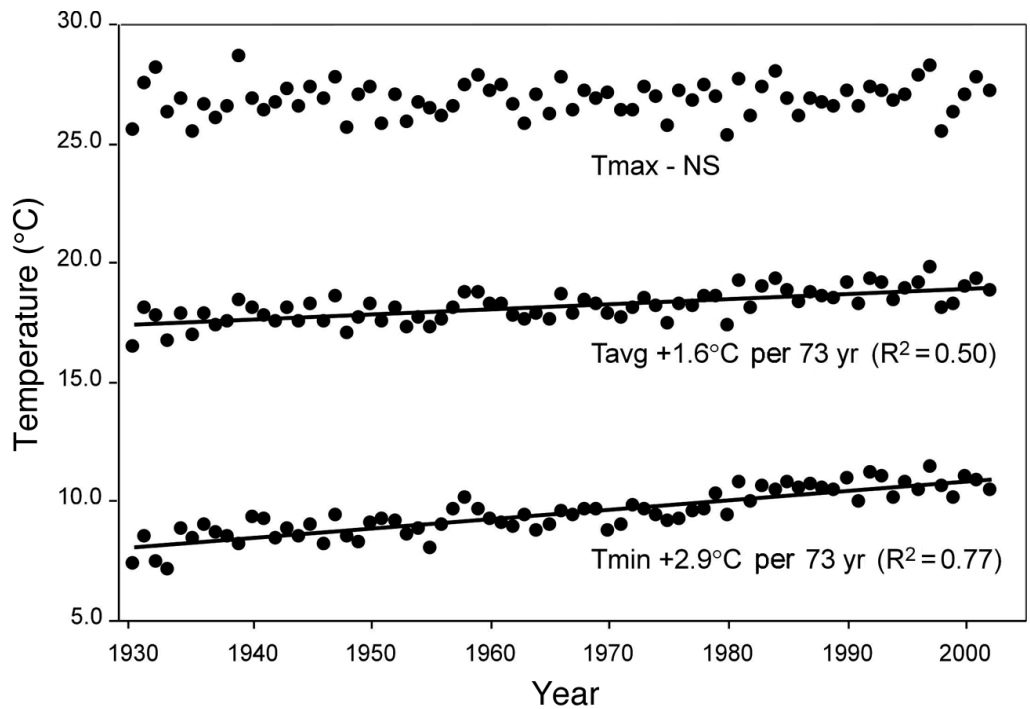

Fig. 5. Annual growing season (1 April to 31 October) average, maximum and minimum temperature values and trends over the period from 1930 to 2002 for the Napa Valley (the full descriptive and trend statistics are given in Table 4). Tavg: growing season average temperature; Tmin: growing season average temperature; NS: not significant

warmed by $1.5^{\circ} \mathrm{C}$. The number of days below $0^{\circ} \mathrm{C}$ in all seasons has declined significantly (-29 d annually, $-6 \mathrm{~d}$ in the spring, and $-6 \mathrm{~d}$ in the fall), while the average date of last spring and first fall frost was $44 \mathrm{~d}$ earlier and $41 \mathrm{~d}$ later, respectively (Table 4 ). The result was a longer frost-free period of $85 \mathrm{~d}$ in the Napa Valley over the last 73 yr. However, precipitation levels during the winter, growing season, and bloom and ripening periods have not changed significantly.

\subsection{Teleconnection analysis}

In general, ENSO phase was not a significant factor in many of the variables that are important to wine production. El Niño years were slightly warmer with more GDDs and fewer frost days than La Niña, but the differences were not statistically significant (not shown). In addition, El Niño winters were wetter than La Niña in California, while El Niño winters were drier than La Niña in Oregon and Washington, but the differences were not significant (not shown). For most climate variables, years of neutral ENSO were in between El Niño and La Niña, except for spring and summer precipitation (wetter than both El Niño and La Niña in 8 of 10 regions) and spring ripening temperatures (warmer than both in 6 of 10 regions). It was speculated that the main reason that ENSO phase does not significantly affect climate variables important to wine production is because ENSO is a teleconnection that primarily impacts winter precipitation and generally weakens into spring and summer and thus is often of secondary importance to other synoptic mechanisms. While winter precipitation has not been shown here to directly impact winegrape production, ENSO likely has an indirect effect through the soil-water balance in the spring and entering the growing season. However, the result that suggests years of neutral ENSO are wetter than normal in the western United States wine regions during spring and summer was very important when the PDO phase was considered (below).

While ENSO proved to be relatively unimportant to winegrape production, PDO phase was highly significant for many of the climate variables over the period from 1948 to 1998 (Table 5). PDO was highly significant $(\mathrm{p} \ll 0.05)$ in most $(7$ of 10$)$ wine regions for 8 of the 11 temperature variables. Unlike ENSO, there were no significant differences in precipitation during any season. In general, cold PDO was associated with low temperatures in every season and the increased likelihood of spring frost. The variables of minimum

Table 5. Climate variables important to winegrape production during the cold phase of the Pacific Decadal Oscillation (relative to the warm phase) for all regions in the western United States from 1948 to 1998 and the Napa Valley from 1930 to 1998. Bold: significant $(\mathrm{p}<0.05)$ for Napa Valley or in $90 \%$ of the wine regions. Italics: significant $(\mathrm{p}<0.05)$ in $90 \%$ of the wine regions. Precipitation variables for the wine regions are not significant and not listed

\begin{tabular}{|c|c|c|c|}
\hline Variable & $\begin{array}{l}\text { All regions } \\
1948-1998\end{array}$ & $\begin{array}{l}\% \text { Regions } \\
\quad<0.05\end{array}$ & $\begin{array}{l}\text { Napa Valley } \\
1930-1998\end{array}$ \\
\hline $\begin{array}{l}\text { Growing season average } \\
\text { temperature (Tavg) }\end{array}$ & 0.8 cooler & 80 & 0.4 cooler \\
\hline $\begin{array}{l}\text { Growing season maximum } \\
\text { temperature (Tmax) }\end{array}$ & 0.2 cooler & 0 & 0.2 cooler \\
\hline $\begin{array}{l}\text { Growing season minimum } \\
\text { temperature (Tmin) }\end{array}$ & 1.3 cooler & 90 & 0.5 cooler \\
\hline $\begin{array}{l}\text { Ripening season average } \\
\text { temperature (RTavg) }\end{array}$ & 0.6 cooler & 20 & 0.1 cooler \\
\hline $\begin{array}{l}\text { Growing degree-days (Apr-Oct) } \\
\text { (GDD) }\end{array}$ & 155 less & 70 & 173 less \\
\hline Annual days $<0^{\circ} \mathrm{C}$ & 9 more & 70 & 9 more \\
\hline Spring days $<0^{\circ} \mathrm{C}$ (Mar-May) & 5 more & 100 & 3 more \\
\hline Fall days < $<0^{\circ} \mathrm{C}$ (Sep-Nov) & 1 more & 20 & 1 more \\
\hline Last spring frost $\left(0^{\circ} \mathrm{C}\right)$ & 15 d later & 100 & 29 d later \\
\hline First fall frost $\left(0^{\circ} \mathrm{C}\right)$ & $6 \mathrm{~d}$ earlier & 50 & $5 \mathrm{~d}$ earlier \\
\hline Frost free days $\left(0^{\circ} \mathrm{C}\right)$ & $21 \mathrm{~d}$ less & 90 & 33 d less \\
\hline $\begin{array}{l}\text { Ripening period precipitation } \\
\text { (15 Aug-15 Oct) }\end{array}$ & & & $22.5 \mathrm{~mm}$ more \\
\hline
\end{tabular}


temperature, number of spring frost days, date of last spring frost, and the number of frost-free days were significantly different (more frost) during the cold PDO compared to the warm PDO in nearly all of the wine regions of the western United States. The analysis for Napa Valley from 1930 to 1998 finds similar, albeit slightly different results compared to the western United States wine regions. The impact of cold PDO was significant for 8 of the 15 climate variables for the Napa Valley (Table 5). Growing season average and minimum temperatures were lower during the cold PDO, which leads to less heat accumulation (GDDs). In addition, there were more days below $0^{\circ} \mathrm{C}$ on an annual and spring basis, the date of the last spring frost was nearly a month later, and the frost-free period was $33 \mathrm{~d}$ shorter during the cold PDO. Finally, during the cold PDO there was typically more precipitation during the ripening period (15 August to 15 October). While the case for the PDO being a primary mechanism influencing western United States wine production is strong, one could argue that the PDO phases just coincide with climate warming. To further investigate this argument, ENSO phases were split by PDO phases and related to climate structure and trends in the western United States wine regions.

Not surprisingly, when years of El Niño, La Niña, and neutral ENSO were stratified by PDO phase, the ENSO phases that occurred during the cold PDO had significantly lower minimum temperatures than years of warm PDO (Table 6). As before, none of the precipitation variables showed significant differences when ENSO years are split by PDO phase (not shown). However, aside from these expected similarities, the impact of PDO on ENSO was different for El Niño, La Niña, and neutral ENSO. When El Niño years were split by PDO phase, 5 of the 6 frost variables showed significant increases for at least $70 \%$ of the wine regions during the cold PDO (Table 6). The length of the frostfree growing season was significantly shorter $(p<0.05)$ in all 10 wine regions (by an average of $28 \mathrm{~d}$ ) when El Niño occurred during the cold phase of the PDO. Years of neutral ENSO had significantly more spring frost, fewer GDDs, and a shorter frost-free growing season in at least half of the wine regions during the cold phase of the PDO. Unlike El Niño and neutral ENSO, however, years of La Niña were not significantly impacted by PDO phase for any variable outside of minimum temperatures. While the PDO and, to a lesser extent, ENSO are shown to impact the climate variables important to winegrape production, especially with regards to minimum temperatures and winter and spring frost, it is not yet conclusive how the teleconnections impact actual wine quality. For that, we conducted a similar analysis using 'Wine Spectator' vintage ratings.

\section{3. 'Wine Spectator' rating analysis}

Further evidence that El Niño events are not associated with poor vintages is shown by Table 7. During the $19 \mathrm{yr}$ of El Niño the WSR averaged 88.7 and had relatively little variability. Both La Niña and years of neutral ENSO had WSR that averaged slightly less than that of El Niño, but both had far greater variability as represented by the standard deviation being nearly twice that of El Niño years. While El Niño is shown to be associated with higher WSR, the differences between ENSO phases are not statistically significant. This was not the case for mean WSR split by PDO phase (Table 7). Years in a cold PDO phase have significantly lower WSR compared to years in a warm PDO phase $(\mathrm{p}<0.01)$. While the PDO results were expected, the truly surprising results are shown by Table 8. The subset of ENSO-PDO years associated

Table 6. Number of western United States wine regions (out of 10) where temperature variables are significantly different for each El Niño-Southern Oscillation phase when stratified by Pacific Decadal Oscillation phases over the period from 1948 to 1998 . Note that none of the precipitation variables are significant at the 0.05 level and are therefore not listed here

\begin{tabular}{|lccc|}
\hline Variable & El Niño & La Niña & Neutral \\
\hline $\begin{array}{l}\text { Growing season average } \\
\text { temperature (Tavg) }\end{array}$ & 0 & 2 & 6 \\
$\begin{array}{l}\text { Growing season maximum } \\
\quad \text { temperature (Tmax) }\end{array}$ & 1 & 1 & 0 \\
$\quad$ Growing season minimum & 5 & 6 & 8 \\
$\quad$ temperature (Tmin) & & & \\
$\quad$ Ripening season average & 0 & 2 & 0 \\
$\quad$ temperature (RTavg) & & & \\
Growing degree-days & 0 & 2 & 6 \\
$\quad$ Apr-Oct) (GDD) & & & \\
Annual days $<0^{\circ} \mathrm{C}$ & 7 & 0 & 2 \\
Spring days $<0^{\circ} \mathrm{C}(\mathrm{Mar}-\mathrm{May})$ & 7 & 1 & 6 \\
Fall days $<0^{\circ} \mathrm{C}(\mathrm{Sep}-\mathrm{Nov})$ & 7 & 0 & 0 \\
Last spring frost $\left(0^{\circ} \mathrm{C}\right)$ & 8 & 2 & 6 \\
First fall frost $\left(0^{\circ} \mathrm{C}\right)$ & 4 & 0 & 0 \\
Frost free days $\left(0^{\circ} \mathrm{C}\right)$ & 10 & 0 & 5 \\
\hline
\end{tabular}

Table 7. Descriptive statistics of the 'Wine Spectator' vintage ratings (WSR) for Cabernet Sauvignon wines from the Napa Valley split by teleconnection phase from 1933 to 1998. PDO: Pacific Decadal Oscillation; *differences between El NiñoSouthern Oscillation phases not significant; ${ }^{* *}$ difference between cold and warm PDO highly significant $(p<0.01)$

\begin{tabular}{|lccccc|}
\hline Phase & $\mathrm{N}$ & Mean & $\mathrm{SD}$ & $\mathrm{SEM}$ & $\mathrm{CI}_{95 \mathrm{th}}$ \\
\hline El Niño* & 19 & 88.7 & 4.8 & 1.1 & $86.4-91.0$ \\
La Niña & 17 & 85.3 & 9.2 & 2.2 & $80.6-90.0$ \\
Neutral & 30 & 84.4 & 8.9 & 1.6 & $81.1-87.7$ \\
Warm PDO** $^{*}$ & 36 & 88.2 & 6.1 & 1.0 & $86.2-90.2$ \\
Cold PDO & 30 & 83.1 & 9.4 & 1.7 & $79.6-86.6$ \\
\hline
\end{tabular}


Table 8. Descriptive statistics of the 'Wine Spectator' vintage ratings (WSR) for Cabernet Sauvignon wines from the Napa Valley when the El Niño-Southern Oscillation phase was split by the Pacific Decadal Oscillation phase from 1933 to 1998

\begin{tabular}{|lrcccc|}
\hline Phase (significance) & N & Mean & SD & SEM & CI $_{95 \text { th }}$ \\
\hline El Niño-warm PDO & 11 & 87.7 & 5.2 & 1.6 & $84.1-91.3$ \\
El Niño-cold PDO & 8 & 90.1 & 4.1 & 1.4 & $86.8-93.4$ \\
$\mathrm{p}>0.3$ & & & & & \\
La Niña-warm PDO & 6 & 88.8 & 6.8 & 2.8 & $81.6-96.0$ \\
La Niña-cold PDO & 11 & 83.4 & 10.1 & 3.0 & $76.7-90.1$ \\
$\mathrm{p}>0.2$ & & & & & \\
Neutral ENSO-warm PDO & 19 & 88.3 & 6.7 & 1.5 & $85.1-91.5$ \\
Neutral ENSO-Cold PDO & 11 & 77.7 & 8.5 & 2.6 & $71.9-83.5$ \\
$p \ll 0.01$ & & & & & \\
\hline
\end{tabular}

temperatures. PC3 explained $15.2 \%$ of the variation and is represented by the timing and frequency of frosts in the fall. PC4 explained $10.3 \%$ of the variation and loaded positively with growing season and bloom period rainfall, while PC5 explained $8.8 \%$ of the remaining variability and is represented by winter and ripening period precipitation. While PC1, PC2, and PC5 are significantly correlated to WSR (Table 10), when all 5 PCs were subjected to a stepwise multiple regression with WSR, a 4 variable model with PC1, PC2, PC4, and PC5 explained $37 \%$ of the variation in WSR over the period from 1933 to 1998. Regression coefficients for PC1 and PC2 are both positive, with PC2 having the with the highest ratings was El Niño-cold PDO, while the lowest ratings by far were associated with neutral ENSO-cold PDO. The 8 yr of El Niño-cold PDO average 90.1, although this result was not significantly different than during El Niño-warm PDO (87.7). The 11 yr of neutral ENSO-cold PDO had a mean WSR of 77.7, which was significantly different $(\mathrm{p} \ll 0.01)$ than the WSR of neutral ENSO-warm PDO (88.3). The next lowest ENSO-PDO subset was La Niña-cold PDO, which had a mean WSR of 83.4. Clearly, years of neutral ENSO-cold PDO are not likely to produce high quality wine. This is borne out by the following facts. The highest WSR during the 11 yr of neutral ENSOcold PDO was 87. The highest WSR of the other 5 ENSO-PDO subsets ranged from 95 to 98 . In fact, the other 5 ENSO-PDO subsets have at least $44 \%$ of their years with a WSR of at least 90 . Table 9 shows that years of neutral ENSO-cold PDO produced 5 of the 7 lowest WSRs, while the other 5 ENSO-PDO subsets were each represented in a similar listing of the highest WSRs. Remarkably, the subsets of years with the best and worst quality WSR, respectively, both occurred during the cold PDO from 1947 to 1976. While the fact that the lowest quality vintages were associated with the cold PDO was expected, the fact that some of the highest quality vintages of the past 66 yr occurred at the same time was not.

To determine which climate variables are the best predictors of WSR, a PCA was performed on the 15 climate variables for the Napa Valley (1933 to 1998, truncated to match the PDO; see Section 2) with a varimax rotation to simplify interpretation. Overall, 5 significant components explaining $82 \%$ of the initial variation were retained (Table 10). The leading mode of variability among the climate variables can be considered the spring frost/cool growing season PC (26.4\%). The second component explained $21.0 \%$ of the remaining climate structure and is related to growing and ripening season heat accumulation or average greatest impact on WSR and indicating that warm growing seasons, followed by warm ripening periods, result in higher ratings. PC1 has the next largest influence on vintage ratings, with fewer and earlier last spring frosts, a longer than normal frost-free period, and followed by relatively cool nights during the growing season. PC4 and PC5 have negative regression coefficients, showing that rainfall during the growing season and bloom and ripening periods resulted in lower vintage ratings and that previous winter rainfall was related to higher ratings.

Comparing these results to the teleconnection analysis for the Napa Valley above (1930 to 1998) showed that spring frost, cooler and shorter growing seasons, and ripening period precipitation were significantly associated with the cold PDO phase and that winter, spring, and summer precipitation were mostly asso-

Table 9. The top and bottom 10 percentiles of 'Wine Spectator' vintage ratings (WSR) for Cabernet Sauvignon wines from the Napa Valley with that year's Pacific Decadal Oscillation (PDO)-El Niño-Southern Oscillation (ENSO) combination. The top 10 percentiles contain $9 \mathrm{yr}$ instead of 7 because of ties

\begin{tabular}{|lccl|}
\hline & Year & WSR & ENSO-PDO \\
\hline Top & 1997 & 98 & Neutral ENSO-warm PDO \\
& 1985 & 97 & La Niña-warm PDO \\
& 1968 & 96 & La Niña-cold PDO \\
& 1987 & 96 & El Niño-warm PDO \\
& 1994 & 96 & Neutral ENSO-warm PDO \\
& 1958 & 95 & El Niño-cold PDO \\
& 1970 & 95 & El Niño-cold PDO \\
& 1986 & 95 & La Niña-warm PDO \\
& 1990 & 95 & Neutral ENSO-warm PDO \\
& 1953 & 67 & Neutral ENSO-cold PDO \\
& 1972 & 67 & La Niña-cold PDO \\
1971 & 68 & La Niña-cold PDO \\
& 1948 & 69 & Neutral ENSO-cold PDO \\
& 1962 & 69 & Neutral ENSO-cold PDO \\
& 1963 & 69 & Neutral ENSO-cold PDO \\
& 1961 & 71 & Neutral ENSO-cold PDO \\
\hline
\end{tabular}


Table 10. Principal components analysis with varimax rotation of the 15 climate variables observed for the Napa Valley from 1933 to 1998. The signs for the variables in each PC represent how they load (positive or negative) on the components. Correlation and significance of each PC with 'Wine Spectator' vintage ratings (WSR) are shown at bottom. Bold: PCs with a significant relationship to the WSR. Var.: \% variance explained of rotated eigenvectors

\begin{tabular}{|c|c|c|c|c|c|}
\hline & PC1 & PC2 & PC3 & PC4 & PC5 \\
\hline Var. (\%) & 26.4 & 21.0 & 15.2 & 10.3 & 8.8 \\
\hline $\mathrm{PC}$ & $\begin{array}{c}\text { (-) Last frost } \\
\text { (+) Frost free } \\
(-) \text { Spring }<0^{\circ} \mathrm{C} \\
\text { (+) Tmin }\end{array}$ & $\begin{array}{c}\text { (+) GDD } \\
\text { (+) Tmax } \\
\text { (+) Tavg } \\
\text { (+) RTavg }\end{array}$ & $\begin{array}{l}(-) \text { Fall }<0^{\circ} \mathrm{C} \\
(+) \text { First frost }\end{array}$ & $\begin{array}{c}\text { (+) GSPrecip } \\
\text { (+) BPrecip }\end{array}$ & $\begin{array}{l}\text { (-) Wprecip } \\
\text { (+) Rprecip }\end{array}$ \\
\hline$r$ & 0.32 & 0.38 & -0.05 & -0.21 & -0.28 \\
\hline $\mathrm{p}$ & 0.01 & 0.01 & 0.71 & 0.09 & 0.02 \\
\hline
\end{tabular}

wine ratings, the analysis revealed that nearly all cases ( 5 of 7 ) of very poor vintages according to the WSRs for Napa Valley Cabernet Sauvignon $(<75)$ were associated with years of neutral ENSO during the cold phase of the PDO. These low-rated vintages generally experience cold springs, cooler than average growing seasons with aboveaverage rainfall in the growing season and ripening period, which can produce greater risks and challenges to wine production and quality through bud damage, flowering and fruit set problems, as well as moisture-related disease pressure (Jones 1997).

ciated with neutral ENSO. This result clarifies the relationship between neutral ENSO-cold PDO and low quality wines. Years with low vintage ratings for Cabernet Sauvignon wines from the Napa Valley typically have shorter than average growing seasons driven by cold springs, followed by above average precipitation during bloom, the summer, and the ripening period. Checking the climate variables for the 10th percentile WSR (of which 5 of 7 are neutral ENSO-cold PDO) shows that, on average, years with WSR $<75$ had a growing season that started 20 d later than normal due to frost and experienced $200 \%$ of normal growing season precipitation.

\section{CONCLUSIONS}

The goal of this analysis was to determine how regional climate teleconnections such as the El NiñoSouthern Oscillation (ENSO) and the Pacific Decadal Oscillation (PDO) relate to climate variables important to winegrape production in the primary growing areas of the western United States as well as to wine quality in the Napa Valley. This research found that the 2 phases of ENSO, including El Niño, which is often misconstrued by growers as being detrimental to vintages (Jones 2005a), did not exhibit a significant association with most wine region climate variables or vintage ratings. The PDO, however, was significantly associated with most temperature variables as well as ratings of wine quality in Napa, with the cold phase associated with colder springs, increased frost risk, shorter growing seasons, precipitation during ripening, and lower ratings.

The most surprising result of this study was that the ENSO-PDO subsets associated with some of the highest and lowest quality wine both occurred from 1947 to 1976 , a time when wine quality was much more unpredictable than during the past $20 \mathrm{yr}$. While any number of ENSO-PDO combinations can lead to higher
Given that this analysis shows that climate explained only $37 \%$ of the variation in vintage ratings in Napa, the question arises as to what other factors are influencing the rest of the variation or trend? Vierra (2004) argues that some of the trend toward increased quality scores is due to the tendency for wines that are higher in alcohol and which have more concentrated flavor profiles to be rated higher by wine critics. Vierra (2004) along with Jones (2005a) also notes that during later half of the 20th century, changes in winemaking technology, better plant material, and better vineyard management have decreased the year-to-year variability in quality, making it much less likely to see such low ratings as those experienced during the 1940s through the 1970s.

Other research has pointed to potential changes in wine production and quality globally and across the western United States due to observed and projected climate change. Using vintage ratings for wine regions throughout the world, Jones et al. (2005) found that quality thresholds exist for many regions, with some being pushed to the brink of their optimum climate for the varieties currently planted and wine styles currently produced. Forcing a high-resolution $(25 \mathrm{~km})$ regional climate model with the IPCC A2 greenhouse gas emission scenario, White et al. (2006) estimated that the potential premium winegrape production area in the United States could decline by up to $81 \%$ by the late 21 st century. The research found that increases in heat accumulation will likely shift wine production to warmer climate varieties and/or lower quality wines. Additionally, the models show that, while frost constraints will likely be reduced, increases in the frequency of extremely hot days $\left(>35^{\circ} \mathrm{C}\right)$ in the growing season are projected to completely eliminate winegrape production in many areas of the United States. Furthermore, grape and wine production will likely be restricted to a narrow West Coast region and the Northwest and Northeast, areas where excess mois- 
ture is already problematic (White et al. 2006). Lobell et al. (2006) further substantiated the work by White et al. (2006) by finding that projections of climate change in California reduced yield across the most important perennial crops in California, including winegrapes, and noted the substantial shifts in suitability for winegrape cultivation to more coastal and northern counties.

However, the results of this research suggest that natural oscillations in Pacific sector climate variability may be just as important, or more so, to the wine industry than climate change, although increased warming may mitigate a return to the cold phase of the PDO. Overland \& Wang (2007) describes how modeling results suggest that the decadal variability in the North Pacific SSTs will continue nearly the same through the 21st century, but that the influence of an upward trend in SSTs will become increasingly evident. Newman (2007) also finds predictability in ENSO-PDO on the order of $2 \mathrm{yr}$ or less that is related to the coupling of the 2 teleconnections, which may result in 'regime shifts' that are the sum of several phenomena. Furthermore, while the current phase of the PDO is uncertain (N. J. Mantua pers. comm.), some believe that the PDO was in the cold phase from 1999 to 2002. The WSRs suggest this may be the case since the 5 yr moving average of the WSR appears headed downward since 1997, and the years of 1998 (86), 2000 (87), and 2002 (87.5) were much lower than the 5 yr moving average and were the first years with a WSR of < 90 since the late 1980s. While increased climate warming may help to stave off a return to WSRs of $<75$, wine producers should be prepared for more variable wine quality should a prolonged cold phase of the PDO develop.

Acknowledgements. The authors appreciate the help of Dale P. Kaiser from the Carbon Dioxide Information Analysis Center (CDIAC), Environmental Sciences Division, Oak Ridge National Laboratory for his help with the USHCN data. We also appreciate the discussion with Nate Mantua from the University of Washington's Climate Impacts Group on the current state of the PDO. Thanks also go to Rod Smith for his help with the cartography.

\section{LITERATURE CITED}

An SI, Kug JS, Timmermann A, Kang IS, Timm O (2007) The influence of ENSO on the generation of decadal variability in the North Pacific. J Clim 20:667-680

Ashenfelter O, Jones GV (2000) The demand for expert opinion: Bordeaux wine. In: Proc VDQS Annual Meeting, Ajaccio, Corsica. Cah Sci, Observatoire des Conjonctures Vinicoles Europeenes, Faculte des Sciences Economiques, Espace Richter, Montpellier

Ashenfelter O, Ashmore D, Lalonde R (1995) Bordeaux wine quality and the weather. Chance 8:7-19

$>$ Chavez FP, Ryan J, Lluch-Cota SE, Niquen M (2003) From anchovies to sardines and back: multidecadal change in the Pacific Ocean. Science 299:217-221
Easterling DR, Karl TR, Lawrimore J, DelGreco S, (1999) United States Historical Climatology Network daily temperature, precipitation, and snow data for 1871-1997. Carbon Dioxide Information and Analysis Center, Publ. 4887, NDP-070, Oak Ridge National Laboratory, Oak Ridge, TN

Esteves MA, Orgaz MDM (2001) The influence of climatic variability on the quality of wine. Int $\mathrm{J}$ Biometerol 45: $13-21$

Frauenfeld OW, Davis RE, Mann ME (2005) A distinctly interdecadal signal of Pacific Ocean-Atmosphere interaction. J Clim 18:1709-1718

Gedalof Z, Mantua NJ, Peterson DL (2002) A multi-century perspective of variability in the Pacific Decadal Oscillation: new insights from tree rings and coral. Geophys Res Lett 29(24):2204

Gershunov A, Barnett TP (1998) Interdecadal modulation of ENSO teleconnections. Bull Am Meteorol Soc 79:2715-2725

Glantz MH (2001) Currents of change: impacts of El Niño and La Niña on climate and society. Cambridge University Press, Cambridge

Goodrich GB (2007) Influence of the Pacific Decadal Oscillation on winter precipitation and drought during years of neutral ENSO. Weather Forecast 22:116-124

Gutzler DS, Kann DM, Thornbrugh C (2002) Modulation of ENSO-based long-lead outlooks of southwestern US winter precipitation by the Pacific Decadal Oscillation. Weather Forecast 17:1163-1172

Hare SR, Mantua NJ (2000) Empirical evidence for North Pacific regime shifts in 1977 and 1989. Prog Oceanogr 47:103-146

Jones GV (1997) A synoptic climatological assessment of viticultural phenology. PhD Dissertation, University of Virginia, Charlottesville, VA

Jones GV (2005a) How hot is too hot? Wine Business Monthly $7(2)$ :February 2005

Jones GV (2005b) Climate change in the western United States grape growing regions. Acta Hortic 689:41-60

Jones GV, Davis RE (2000) Climate influences on grapevine phenology, grape composition, and wine production and quality for Bordeaux, France. Am J Enol Vitic 51:249-261

Jones GV, Storchmann K (2001) Wine market prices and investment under uncertainty: an econometric model for Bordeaux Crus Classés. Agric Econ 26:115-133

Jones GV, White MA, Cooper OR, Storchmann K (2005) Climate change and global wine quality. Clim Change 73: 319-343

Kaplan A, Cane M, Kushnir Y, Clement A, Blumenthal M, Rajagopalan B (1998) Analyses of global sea surface temperature 1856-1991. J Geophys Res 103:18567-18589

Laube J (1989) California's great cabernets: the Wine Spectator's ultimate guide for consumers, collectors and investors. Wine Spectator Press, New York, NY

Lobell DB, Field CB, Cahill KN, Bonfils C (2006) Impacts of future climate change on California perennial crop yields: model projections with climate and crop uncertainties. Agric For Meteorol 141:208-218

Mantua NJ, Hare SR (2002) The Pacific Decadal Oscillation. J Oceanogr 58:35-44

Mantua NJ, Hare SR, Zhang Y, Wallace JM, Francis RC (1997) A Pacific interdecadal climate oscillation with impacts on salmon production. Bull Am Meteorol Soc 78:1069-1079

McCabe GJ, Dettinger MD (1999) Decadal variations in the strength of ENSO teleconnections with precipitation in the western United States. Int J Climatol 19:1399-1410

Nemani RR, White MA, Cayan DR, Jones GV, Running SW, Coughlan JC, Peterson DL (2001) Asymmetric warming over coastal California and its impact on the premium 
wine industry. Clim Res 19:25-34

Newman M (2007) Interannual to decadal predictability of tropical and North Pacific sea surface temperatures. J Clim 20:2333-2356

Newman M, Compo GP, Alexander MA (2003) ENSO-forced variability of the Pacific Decadal Oscillation. J Clim 16: 3853-3857

Overland JE, Wang E (2007) Future climate of the North Pacific Ocean. Eos Trans Am Geophys Union 88(16): 178-182

Reisman CA, Matthews MA, Block DE (2003) Analysis of the effects of weather on California north coast cabernet sauvignon vintage quality. In: Proceedings of the ASEV 53rd annual meeting. Am J Enol Vitic 54(2)139-142

Rodo X, Comin FA (2000) Links between large-scale anomalies, rainfall and wine quality in the Iberian Peninsula during the last three decades. Glob Change Biol 6:

Editorial responsibility: Nils Chr. Stenseth, Oslo, Norway
$267-273$

Schneider N, Cornuelle BD (2005) The forcing of the Pacific Decadal Oscillation. J Clim 18:4355-4373

Schwing F, Moore C (2000) A year without a summer for California, or a harbinger of a climate shift? Eos Trans Am Geophys Union 81(27):301, 304-305

Trenberth KE (1997) The definition of El Niño. Bull Amer Meteor Soc 78:2771-2777

Vierra G (2004) Pretenders at the table-Are table wines no longer food friendly? Wine Business Monthly 11(7):July 2004

White MA, Diffenbaugh NS, Jones GV, Pal JS, Giorgi F (2006) Extreme heat reduces and shifts United States premium wine production in the 21st century. Proc Natl Acad Sci USA 103:11217-11222

Wine Spectator (2004) Wine Spectator's ultimate buying guide, 8th edn. Running Press, Philadelphia, PA

Submitted: July 30, 2007; Accepted: October 16, 2007

Proofs received from author(s): February 6, 2008 